\title{
Most Innovative Asia-Pacific Universities
}

\subsection{Introduction to Ranking}

Despite of the political instability in South Korea, there are strong and solid relations between universities and industry. These relations continue to lead economic growth and technical innovation in this country. This is the conclusion reached by Reuters in the third annual classification of Asian and Pacific universities, working on achieving progress in sciences and creating new technologies [29]. Korea Advanced Institute of Science and Technology, currently known as KAIST, is ranked the first for the third year in a row. Historically speaking, KAIST is the oldest Korean university dedicated for research, sciences, and engineering. It has three branch campuses in the following cities: Daejeon, Seoul, and Busan. The university produces a large number of innovations and applies for more patents than the other 75 universities on the list. In addition, researchers all over the world cite highly the research and patents of this university.

The second ranked on the Asia-Pacific's Most Innovative Universities list was occupied by the ancient Japanese University of Tokyo, which moved from the third (in 2017) to the second position (in 2018). Pohang University of Science \& Technology (POSTECH) came in the third position, achieving a progress from the fourth position in 2017. It is worth mentioning that POSTECH was established by POSCO, a South Korean steel-making company, in 1986. POSTECH is the top university in terms of the number of scientific papers, submitted by industrial researchers, and the number of citations taken from POSTECH papers and found in scientific papers submitted by the private sector.

As for the fourth position, it was occupied by Seoul National University (SNU), which was established in 1946 as the first national university. It received a support worth USD 68 million (KRW76 billion) accounting for $15 \%$ of the total funds from external industries. It is known that universities in South Korea have close relations with industry. Classified the second in 2017, this university is two positions back in the list. Meanwhile, Chinese Tsinghua University moved from the sixth (in 2017) to the fifth (in 2018).

In addition, three non-ranked Chinese universities have joined the 2018 list of Asia-Pacific that includes 75 universities increasing the number of innovative Chinese universities to 27, three of which are located in Hong Kong. Meanwhile, the number of South Korean listed universities dropped from 22 (in 2017) to 20 (in 2018). However, the number remains more than expected from a country with a population of less than 51 million people, compared to China whose population is more than 1370 million people. On the other hand, Japan maintained its 19 universities in the ranking list for the second year in a row.

Although India's population has grown more than 1280 million people, only one Indian university, the Indian Institutes of Technology (IIT), joined the list. The institute is a network of 23 universities with a central management of patents, which makes it difficult to know to which university a research paper belongs.

Countries with no ranking in the list include: Indonesia, Pakistan, and Bangladesh, the third, fourth, and fifth Asian countries in terms of population, respectively. In addition, there are no universities from either the Arabian Gulf, the Philippines, or Vietnam in the list, despite of their huge economies [29].

\subsection{Table of Asia-Pacific's Most Innovative Universities}

Table 5.1 shows the Asia-Pacific's Most Innovative Universities in 2018 [29]. This is the most recent rankings when this book was composed. It lists the 75 Most Innovative Universities in this region.

From Table 5.1, it is clear that the highest number of the Asia-Pacific's Most Innovative Universities in 2018 is in China. In Table 5.2, the numbers of Asia-Pacific's Most Innovative Universities in 2017 and 2018 in the different countries are given for comparison. 
Table 5.1. Asia-Pacific's most innovative universities in 2018

\begin{tabular}{|c|c|c|}
\hline Rank & Institution & Country \\
\hline 1 & Korea Advanced Institute of Science and Technology (KAIST) & South Korea \\
\hline 2 & University of Tokyo & Japan \\
\hline 3 & Pohang University of Science and Technology (POSTECH) & South Korea \\
\hline 4 & Seoul National University & South Korea \\
\hline 5 & Tsinghua University & China \\
\hline 6 & Osaka University & Japan \\
\hline 7 & Kyoto University & Japan \\
\hline 8 & Sungkyunkwan University & South Korea \\
\hline 9 & Tohoku University & Japan \\
\hline 10 & National University of Singapore & Singapore \\
\hline 11 & Hanyang University & South Korea \\
\hline 12 & Peking University & China \\
\hline 13 & Yonsei University & South Korea \\
\hline 14 & Kyushu University & Japan \\
\hline 15 & Korea University & South Korea \\
\hline 16 & Tokyo Institute of Technology & Japan \\
\hline 17 & Fudan University & China \\
\hline 18 & Keio University & Japan \\
\hline 19 & Shanghai Jiao Tong University & China \\
\hline 20 & Gwangju Institute of Science and Technology & South Korea \\
\hline 21 & Zhejiang University & China \\
\hline 22 & Chinese University of Hong Kong & Hong Kong \\
\hline 23 & Hokkaido University & Japan \\
\hline 24 & Kyung Hee University & South Korea \\
\hline 25 & Monash University & Australia \\
\hline 26 & Nanyang Technological University & Singapore \\
\hline 27 & Ajou University & South Korea \\
\hline 28 & Huazhong University of Science and Technology & China \\
\hline 29 & Hiroshima University & Japan \\
\hline 30 & Kumamoto University & Japan \\
\hline 31 & Nagoya University & Japan \\
\hline 32 & Beijing University of Chemical Technology & China \\
\hline 33 & East China University of Science and Technology & China \\
\hline 34 & Tokyo Medical \& Dental University (TMDU) & Japan \\
\hline 35 & Tianjin University & China \\
\hline 36 & University of Sydney & Australia \\
\hline 37 & Ewha Womans University & South Korea \\
\hline 38 & Hong Kong University of Science and Technology & Hong Kong \\
\hline 39 & University of Auckland & New Zealand \\
\hline 40 & Shinshu University & Japan \\
\hline 41 & South China University of Technology & China \\
\hline 42 & University of Queensland & Australia \\
\hline 43 & Kanazawa University & Japan \\
\hline 44 & China University of Petroleum & China \\
\hline 45 & University of Melbourne & Australia \\
\hline 46 & Southeast University China & China \\
\hline
\end{tabular}


Table 5.1. (continued)

\begin{tabular}{|c|c|c|}
\hline Rank & Institution & Country \\
\hline 47 & University of Hong Kong & Hong Kong \\
\hline 48 & University of Tsukuba & Japan \\
\hline 49 & Catholic University of Korea & South Korea \\
\hline 50 & Nanjing University & China \\
\hline 51 & University of New South Wales Sydney & Australia \\
\hline 52 & Chiba University & Japan \\
\hline 53 & Xi'an Jiaotong University & China \\
\hline 54 & Chonbuk National University & South Korea \\
\hline 55 & Chonnam National University & South Korea \\
\hline 56 & China University of Mining And Technology & China \\
\hline 57 & Pusan National University & South Korea \\
\hline 58 & Dalian University of Technology & China \\
\hline 59 & Kayama University & Japan \\
\hline 60 & Kyungpook National University & South Korea \\
\hline 61 & Harbin Institute of Technology & China \\
\hline 62 & Nankai University & China \\
\hline 63 & Chung-Ang University & South Korea \\
\hline 64 & Inha University & South Korea \\
\hline 65 & Sun Yat-sen University & China \\
\hline 66 & Sichuan University & China \\
\hline 67 & Shandong University & China \\
\hline 68 & University of Electronic Science and Technology of China & China \\
\hline 69 & University of Ulsan & South Korea \\
\hline 70 & Waseda University & Japan \\
\hline 71 & Indian Institutes of Technology System (IIT) & India \\
\hline 72 & Kobe University & Japan \\
\hline 73 & Konkuk University & South Korea \\
\hline 74 & Xiamen University & China \\
\hline 75 & Tongji University & China \\
\hline
\end{tabular}

Table 5.2. Numbers of the Asia-Pacific's most innovative universities in the different countries

\begin{tabular}{l|l|l}
\hline Countries & \multicolumn{2}{|l}{$\begin{array}{l}\text { Numbers of the world's most } \\
\text { innovative universities }\end{array}$} \\
\cline { 2 - 3 } & 2017 & 2018 \\
\hline $\begin{array}{l}\text { China (Including } \\
\text { Hong Kong) }\end{array}$ & 24 & 27 \\
\hline South Korea & 23 & 20 \\
\hline Japan & 19 & 19 \\
\hline Australia & 5 & 5 \\
\hline Singapore & 2 & 2 \\
\hline New Zealand & 1 & 1 \\
\hline India & 1 & 1 \\
\hline Total & $\mathbf{7 5}$ & 75 \\
\hline
\end{tabular}


Open Access This chapter is licensed under the terms of the Creative Commons Attribution 4.0 International License (http://creative commons.org/licenses/by/4.0/), which permits use, sharing, adaptation, distribution and reproduction in any medium or format, as long as you give appropriate credit to the original author(s) and the source, provide a link to the Creative Commons license and indicate if changes were made.
The images or other third party material in this chapter are included in the chapter's Creative Commons license, unless indicated otherwise in a credit line to the material. If material is not included in the chapter's Creative Commons license and your intended use is not permitted by statutory regulation or exceeds the permitted use, you will need to obtain permission directly from the copyright holder. 